\title{
ARTICLE
}

\section{Antioxidant and hepatoprotective property of squalene for counteracting the oxidative damage induced by methotrex- ate in experimental rats}

\author{
Edakkukaran Sudhakaran Sumi, Pavan Kumar Dara, Rosemol Jacob Mannuthy, \\ Balaraman Ganesan, Rangasamy Anandan, Suseela Mathew*
}

Biochemistry and Nutrition Division, ICAR-Central Institute of Fisheries Technology, Cochin 682 029, Kerala, India

\begin{abstract}
Methotrexate (MTX), an antifolate drug, is extensively prescribed for patients suffering from diseases like cancer, psoriasis, neoplasms, and rheumatoid arthritis. Despite its effectiveness, MTX sometimes finds limited application because its undesirable side effects, including hepatic or renal impairment, bone marrow toxicity and gastrointestinal mucosal injury. Squalene, a highly unsaturated isoprenoid compound, isolated from shark liver oil has great potential in neutralizing the damaging effects triggered by free radicals. Therefore, in this study, the protective role of dietary squalene supplementation on oxidative stress induced by methotrexate in experimental rats was evaluated. A significant reduction was displayed in the activities of catalase (CAT) and superoxide dismutase (SOD) in MTX-intoxicated groups compared to other groups. Similarly, the activities of glutathione dependant enzymes (GPx and GST) and reduced glutathione (GSH) in MTX-induced groups were shown to be lower compared to the untreated control. Increased LPO (lipid peroxide) level was found in MTX-intoxicated groups compared to other groups. In addition, alterations in the levels of liver marker enzymes like AST, ALP, ALT, and LDH were noticed in MTX intoxicated groups compared to other groups. Biochemical results were confirmed by the histopathological examination of liver sections. In conclusion, the result obtained in the present study proposes that squalene exerts antioxidant activity and is capable of ameliorating oxidative stress and liver injury induced by MTX.

Acta Biol Szeged 64(2):199-206 (2020)
\end{abstract}

\section{KEY WORDS}

hepatotoxicity

histopathology

methotrexate

squalene

ARTICLE INFORMATION

Submitted

01 July 2020

Accepted

22 December 2020

*Corresponding author

E-mail: suseela1962@gmail.com

\section{Introduction}

Methotrexate (MTX) is a widely used anti-neoplastic drug which is considered as first line treatment option to patients suffering with cancer (Uzar et al. 2006a). Additionally, MTX is a prescribed medicine for other diseases like psoriasis, Crohn's disease, autoimmune diseases (e.g., rheumatoid arthritis), immunological abnormalities, and systemic inflammation (Cetinkaya et al. 2006). It causes acute life-threatening side effects in overdose situations (Funk et al. 2013; Schwartzberg et al. 2014). However, the most severe and widespread problems of toxicity associated MTX treatment are fever, non-productive cough and dyspnoea, pneumonitis and pulmonary fibrosis (Imokawa et al. 2000; Jakubovic et al. 2013; Hsu et al. 2003). MTXinduced toxic effect is dependent on the applied dose and found to be occurring up to $60 \%$ of disease cases (Neuman et al. 1999). MTX in higher doses has restricted applications in disease management because of its serious life-threatening effects on liver (Liang et al. 2004).
Methotrexate prevents the formation of tetrahydrofolate (THF) by dihydrofolate reductase (DHFR) and thus decreases reduced folate species and hence, the synthesis of purine and pyrimidine precursors, which are necessary for the synthesis of nucleic acids (Channa Keshava et al. 1998; Goodsell et al. 1999). Johovic et al. (2003) reported that methotrexate inhibits cytosolic enzymatic activities of NADP-dependent dehydrogenases and NADP malic enzyme to reduce the availability of NADPH in cells via pentose phosphate inhibition pathway. However, the exact mechanism underlying the MTX-toxicity remains unclear. Previous studies have hypothesized that MTX application induces oxidative damage in tissues (Miketova et al. 2005; Armagan et al. 2008). Like other anticancer synthetic drugs, oxidative stress is reported to have a significant role in the pathophysiology of tissue toxicity induced by MTX (Atessahin et al. 2005; Fadillioglu et al. 2003; Uz et al. 2005; Quiles et al. 2002). Earlier studies also reported that MTX toxicity results in significant reduction in efficacy of the antioxidant enzymes defence system and increased sensitivity of cells to ROS (Kolli 
et al. 2014; Abd et al. 2016). Antioxidants perform an essential role in living organisms, and they are capable to stop free radical generation. To conquer the adverse effect of MTX toxicity, it has been recommended to use antioxidants (Block et al. 2008; Miyazono et al. 2004).

Squalene is a marine biomolecule having six isoprene units. It is abundantly available in shark liver oil and other sources including olive oil, rice bran oil etc. Squalene is an integral part of Mediterranean diet and is incorporated in traditional medicine as it plays an essential role in the treatment of several diseases. Squalene is a highly effective natural antioxidant, reported to have ability to protect cells from oxidative stress and lipid peroxidation (Kabuto et al. 2013). It is key intermediate in cholesterol metabolism and exerts lipid lowering and membrane stabilizing property (Farvin et al. 2004; Farvin et al. 2005). Detoxifying activities of squalene were studied and was suggested to be having a potential to ameliorate the harmful effects of different compounds namely hexachlorobiphenyl, perchlorobenzene, arsenic, theophylline, phenobarbital and cyclophosphamide (Richter et al. 1982; Kamimura et al. 1992; Fan et al. 1996; Senthilkumar et al. 2006a). Relevant studies reported that squalene exhibits anti-neoplastic effect (Smith 2000; Sotiroudis and Kyrtopoulos 2008). Though squalene has been identified as a natural antioxidant capable of reducing the side effect of anti-cancer agents, the ameliorating effects of squalene against hepatotoxicity associated with MTX administration have not been explored yet. With this rationale, this study was designed to demonstrate the protective role of squalene to counteract the oxidative stress mediated by MTX administration and to serve as a free radical inhibitor.

\section{Materials and methods}

\section{Drug and chemicals}

Methotrexate was procured from Sisco Research Laboratory (Mumbai, India). Squalene was obtained as a kind gift from Aasha Biochem (Kerala, India). Remaining reagents/ chemicals used in this study were of standard analytical chemicals and were obtained either from Sigma Chemical (USA) or Sisco Research Laboratory (Mumbai, India).

\section{Animals}

Ten-week-old male Wistar strain albino rats, weighing 100-120 g were selected for the study. All animals were housed individually in hygienic and standard environmental conditions of temperature $28 \pm 2{ }^{\circ} \mathrm{C}$, humidity $60-70 \%, 12 \mathrm{~h}$ light and $12 \mathrm{~h}$ dark cycle in polypropylene cages. During the experimental period, the animals were fed with a standard diet (M/s Sai Foods, Bangalore, India; the diet contained carbohydrate $56.2 \%$, crude protein $22 \%$, ash $7.5 \%$, total fat $4.2 \%$, crude fibre $3 \%$, glucose $2.5 \%$, vitamin $1.8 \%$, sand silica $1.4 \%$, calcium $0.8 \%$, phosphorus $0.8 \%$, and provide metabolizable energy of $3600 \mathrm{kcal}$.) and water ad libitum. The experiment was carried out according to the guidelines of the Committee for the Purpose of Control and Supervision of Experiments on Animals (CPCSEA), New Delhi, India and approved by the Institutional Animal Ethics Committee of the Central Institute of Fisheries Technology, Cochin.

\section{Experimental design}

The experimental animals were separated into four groups, each group having six animals. Group I (CO-SAL) and Group II (CO-MTX) animals were fed on commercial feed with added coconut oil at 1.5\% level and Group III (SQ-SAL) and Group IV (SQ-MTX) animals were fed on commercial feed with added squalene at $1.5 \%$ level for a period of 30 days. Group I and III were intraperitoneally (i.p.) injected with $0.5 \mathrm{ml}$ normal saline $(0.9 \%)$ and Group II and IV with $0.5 \mathrm{ml}$ methotrexate $(20 \mathrm{mg} / \mathrm{kg}$ body weight) on $30^{\text {th }}$ day (Saeed et al. 2018). During the experimental period body weight of all the animals was properly documented. At the end of the experiment, i.e. $48 \mathrm{~h}$ after the MTX/normal saline administration, the experimental rats were sacrificed. The sera obtained from the collected blood samples were stored properly and used for performing various assays including total protein (Lowry et al. 1951), total bilirubin (Frederick and Robert Lee 1974), AST (Mohur and Cook 1957), ALT (Mohur and Cook 1957), LDH (King 1965a) and ALP (King 1965b). The results obtained for AST, ALT, LDH were expressed in $\mu \mathrm{mol}$ of pyruvate liberated $/ \mathrm{h} / \mathrm{mg}$ protein and ALP in $\mu \mathrm{mol}$ of phenol liberated $\mathrm{h} / \mathrm{mg}$ protein.

Liver samples were weighed, and a small portion of liver tissue was fixed in $10 \%$ buffered formalin for histopathological observations. Accurately weighed liver tissue samples were homogenized in phosphate buffer at $4{ }^{\circ} \mathrm{C}$ with a tissue homogenizer. The homogenate obtained was further centrifuged and the supernatant collected were used for conducting different assays like SOD (Misra and Fridovich 1972), catalase (Takahara et al. 1960), GST (Habig et al. 1974), GSH (Ellman 1959), GPx (Paglia and Valentine 1967) and LPO (Ohkawa et al. 1979). The obtained results were expressed as SOD: one unit of the SOD activity is the amount of protein required to give $50 \%$ inhibition of epinephrine autoxidation. Catalase: $\mu \mathrm{mol} \mathrm{H}_{2} \mathrm{O}_{2}$ decomposed/min/mg protein; GST: $\mu \mathrm{mol}$ 1-chloro-2,4-dinitrobenzene conjugate formed $/ \mathrm{min} /$ mg protein; GSH: $\mu \mathrm{mol} / \mathrm{mg}$ wet tissue; GPx: $\mu \mathrm{mol} \mathrm{GSH}$ oxidized $/ \mathrm{min} / \mathrm{mg}$ protein; LPO: $\mu \mathrm{mol}$ malonaldehyde liberated/mg protein. 
Table 1. Effect of dietary squalene supplementation on body weight and relative liver weight of experiments rats receiving different treatments.

\begin{tabular}{lllll}
\hline Groups & $\begin{array}{l}\text { Group I } \\
\text { (CO-SAL) }\end{array}$ & $\begin{array}{l}\text { Group II } \\
\text { (CO-MTX) }\end{array}$ & $\begin{array}{l}\text { Group III } \\
\text { (SQ-SAL) }\end{array}$ & $\begin{array}{l}\text { Group IV } \\
\text { (SQ-MTX) }\end{array}$ \\
\hline Body weight (g) & $202.66 \pm 2.51^{\mathrm{c}}$ & $181.33 \pm 1.52^{\mathrm{a}}$ & $203.05 \pm 0.50^{\mathrm{c}}$ & $196.66 \pm 2.08^{\mathrm{b}}$ \\
Relative liver weight (\%) & $2.15 \pm 0.06^{\mathrm{a}}$ & $2.94 \pm 0.05^{\mathrm{c}}$ & $2.12 \pm 0.03^{\mathrm{a}}$ & $2.32 \pm 0.01^{\mathrm{b}}$ \\
\hline
\end{tabular}

Values that have a different superscript letter $(a, b, c, d)$ differ significantly $(p<0.05)$ among each other.

\section{Histopathological examination}

Liver tissues were processed by the standard histopathological procedure to observe microscopic changes. Briefly, liver tissue section was embedded in paraffin and $5 \mu \mathrm{m}$ sections were cut separately. The sections were deparaffinized using xylene and ethanol and then washed with PBS and permeabilization solution ( $0.1 \mathrm{M}$ citrate, $0.1 \%$ Triton X-100). The deparaffinised sections were stained with haematoxylin and eosin. The histopathological examination of tissues of animals was carried out under fluorescence microscope (Olympus BX 60, PA, USA).

\section{Statistical analysis}

The results were stated as mean \pm SD for 6 animals. The statistical comparisons among studied groups were performed with SPSS software program (SPSS.16.0 for Windows, SPSS, Chicago, IL) using one-way analysis of variance (ANOVA). Duncan's multiple range comparison tests were performed among groups.

\section{Results and Discussion}

\section{Influence of MTX treatment on body weight and relative liver weight}

In the present study, it was observed that MTX injection at single dose results in the decline of the body weight of both group II and group IV animals. A signifcant reduction in the body weight was found in Group II animals in comparison with other group animals (Table 1). These variations in body weight might possibly be due to oxidative tissue damage in response to MTX induced toxic effect, which was reversed by dietary squalene supple- mentation. Oxidative stress is one of the key mechanisms involved in drugs induced liver toxicity. A reduced body weight in experimental rats after single dose methotrexate injection (i.p.) was reported in previous studies (Moghadam et al. 2015). In addition, it was also reported that the MTX administration (20 mg/kg, single i.p. injection) in experimental rats initiates tissue damage and subsequent weight loss in comparison with normal control rats (Khafaga and El-Sayed 2018). Squalene pretreatment might have inhibited the cell damage due to MTX toxicity and maintained the body weight to near normalcy by its tissue protecting activity against oxidative stress. The results were in line with the previous reports which described that squalene exhibited antioxidant defense mechanism in tissue and protected the cell membrane from oxidative stress (Farvin et al. 2005)

Significant changes observed in the relative liver weight of Group II MTX intoxicated rats (Table 1) possibly due to the oxidative tissue damage induced by methotrexate. Prior treatment with squalene reversed these changes in relative liver weight. In consistence with current study, it has been reported that acute tissue damage and alterations in relative liver weights of experimental rats receiving a single dose methotrexate $(20 \mathrm{mg} / \mathrm{kg}$ body weight) indicated its toxic effect on tissue (Moghadam et al. 2015). Furthermore, other investigators also reported that a single intra-peritoneal injection of MTX initiates oxidative stress which is evidenced by an elevated level of relative liver weight in MTX intoxicated groups compared to control (Asmaa and Yasser 2018; Mukherjee et al. 2013). Prior supplementation of squalene in Group IV animals perhaps protected the liver cell against oxidative damage induced by methotrexate. Squalene is effective

Table 2. Effect of dietary squalene supplementation on total protein and total bilirubin content of experimental rats receiving different treatments.

\begin{tabular}{llll}
\hline Parameters & $\begin{array}{l}\text { Group I } \\
\text { (CO-SAL) }\end{array}$ & $\begin{array}{l}\text { Group II } \\
\text { (CO-MTX) }\end{array}$ & $\begin{array}{l}\text { Group III } \\
\text { (SQ-SAL) }\end{array}$ \\
\hline Total protein $(\mathrm{mg} / 100 \mathrm{ml})$ & $7.57 \pm 0.07^{\mathrm{c}}$ & $5.25 \pm 0.05^{\mathrm{a}}$ & $\begin{array}{l}\text { Group IV } \\
\text { (SQ-MTX) }\end{array}$ \\
Total bilirubin $(\mathrm{mg} / 100 \mathrm{ml})$ & $0.200 \pm 0.00^{\mathrm{a}}$ & $1.30 \pm 0.00^{\mathrm{c}}$ & $0.10 \mathrm{c}$ \\
\hline
\end{tabular}

Values that have a different superscript letter $(a, b, c, d)$ differ significantly $(p<0.05)$ among each other. 
Sumi et al.

Table 3. Effects of dietary squalene supplementation on enzymatic antioxidant levels and lipid peroxide content of experimental rats receiving different treatments.

\begin{tabular}{lllll}
\hline Parameters & $\begin{array}{l}\text { Group I } \\
\text { (CO-SAL) }\end{array}$ & $\begin{array}{l}\text { Group II } \\
\text { (CO-MTX) }\end{array}$ & $\begin{array}{l}\text { Group III } \\
\text { (SQ-SAL) }\end{array}$ & $\begin{array}{l}\text { Group IV } \\
\text { (SQ-MTX) }\end{array}$ \\
\hline SOD & $3.82 \pm 0.01^{\mathrm{d}}$ & $1.04 \pm 0.00^{\mathrm{a}}$ & $3.41 \pm 0.02^{\mathrm{c}}$ & $2.71 \pm 0.02^{\mathrm{b}}$ \\
CAT & $10.23 \pm 0.31^{\mathrm{c}}$ & $2.11 \pm 0.02^{\mathrm{a}}$ & $11.19 \pm 0.26^{\mathrm{d}}$ & $9.48 \pm 0.41^{\mathrm{b}}$ \\
GST & $7.19 \pm 0.02^{\mathrm{c}}$ & $3.88 \pm 0.02^{\mathrm{a}}$ & $7.61 \pm 0.06^{\mathrm{d}}$ & $6.40 \pm 0.04^{\mathrm{b}}$ \\
GSH & $21.48 \pm 0.51^{\mathrm{d}}$ & $7.99 \pm 0.42^{\mathrm{a}}$ & $17.13 \pm 0.20^{\mathrm{c}}$ & $13.96 \pm 0.18^{\mathrm{b}}$ \\
GPX & $2.13 \pm 0.07^{\mathrm{c}}$ & $1.21 \pm 0.10^{\mathrm{a}}$ & $1.91 \pm 0.05^{\mathrm{b}}$ & $1.8 \pm 0.03^{\mathrm{b}}$ \\
LPO & $1.18 \pm 0.03^{\mathrm{a}}$ & $2.99 \pm 0.01^{\mathrm{d}}$ & $1.58 \pm 0.01^{\mathrm{b}}$ & $1.71 \pm 0.02^{\mathrm{c}}$ \\
\hline
\end{tabular}

Values that have a different superscript letter $(a, b, c, d)$ differ significantly $(p<0.05)$ among each other.

in counteracting oxidative stress and cellular damage occurred in tissue by its antioxidant and membrane stabilizing activity. Earlier it was reported that squalene pretreatment in experimental animals effectively restored the impaired tissue that was exposed to drug treatment (Farvin et al. 2004).

\section{Influence of MTX treatment on total protein and total bilirubin level}

Total serum protein levels of MTX administrated groups (Group II and IV) were lower in comparison with other groups (Table 2). Significant decline was noticed in Group II animals when compared with other groups. Observed changes in total protein level depict impaired liver function probably due to methotrexate administration. These observations were in accordance with the previous reports which displayed significant depletion of serum protein level in MTX intoxicated groups than untreated groups (Moghadam et al. 2015). Dietary squalene supplementation helps to maintain the serum total protein levels to near normal in experimental animals. Normalized protein levels in squalene treated group marks its protection of liver functions against methotrexate toxicity. The resultant observation is in accordance with the earlier report which stated that squalene treatment aids to restore serum protein levels to near normal in cyclophosphamide intoxicated groups vs untreated group (Senthilkumar et al. 2006a). The total bilirubin level was found to be increased in Group II animals compared to other groups (Table 2). Squalene supplementation prevented the increase of total bilirubin levels and maintained to normal in group IV animals. Abdulzahra and Mohammed (2014) indicated that total serum bilirubin level was found to be higher in rats treated with MTX group compared with untreated groups. Increased total bilirubin level indicates the hepatotoxicity and these results concur with the previous studies (Moghadam et al. 2015). Squalene provides protection to liver cells and effectively prevents the elevation of serum biochemical parameters by its membrane stabilizing activity. In the present study, prior supplementation of squalene decreased total serum bilirubin levels thereby reduced the biochemical alteration induced by methotrexate. The present results were in accordance with the previous studies (Senthilkumar et al. 2006a).

\section{Effect of dietary squalene on antioxidant enzyme levels of MTX administrated rats}

Table 3 shows the protective action of dietary squalene supplementations on enzymatic and non-enzymatic antioxidant levels as well as lipid peroxide content in experimental groups. SOD and CAT levels in liver tissue were decreased significantly in MTX-administered Group II animals as compared to other animals. This may possibly be due to the formation of superoxide anions and these ions inactivate or reduce the activity of SOD. In fact, SOD and CAT levels of liver induced by MTX treatment causes marked alteration in the antioxidant status, signifying that the cells may possibly be more susceptible to reactive oxygen species (Uzar et al. 2006b), leading to failure in the efficacy of defence mechanism of antioxidant enzymes at cellular level (Miyazono et al. 2004). Squalene is an efficient singlet oxygen scavenging molecule like that of vitamin E. In the present study, squalene in Group IV inhibited MTX induced inactivation of SOD and CAT enzyme activity and retained the cellular antioxidant status to near normal. Antioxidant activity of squalene is assumed to protect the liver cells from cellular damage induced by MTX and these observations were in line with the previous reports (Senthilkumar et al. 2006b).

Methotrexate administration resulted in substantial depletion in GST, GSH, GPx levels in group II compared with others (group I, III and IV). MTX intoxication might have reduced the cellular defence against toxic metabolites in liver of experimental animals. MTX causes significant decrease in antioxidant enzymatic level in experimental animals and supplementation of certain antioxidants like melatonin, taurine is effective in preventing this mechanism. (Jahovic et al. 2003; Cetiner et al. 2005). However, 
Table 4. Effects of dietary squalene supplementation on serum biochemical parameters of experimental rats receiving different treatments.

\begin{tabular}{lllll}
\hline Parameters & $\begin{array}{l}\text { Group I } \\
\text { (CO-SAL) }\end{array}$ & $\begin{array}{l}\text { Group II } \\
\text { (CO-MTX) }\end{array}$ & $\begin{array}{l}\text { Group III } \\
\text { (SQ-SAL) }\end{array}$ & $\begin{array}{l}\text { Group IV } \\
\text { (SQ-MTX) }\end{array}$ \\
\hline AST & $129.28 \pm 0.44^{\mathrm{a}}$ & $274.81 \pm 0.23^{\mathrm{c}}$ & $130.28 \pm 0.28^{\mathrm{a}}$ & $179.81 \pm 0.33^{\mathrm{b}}$ \\
ALT & $136.48 \pm 0.52^{\mathrm{a}}$ & $255.38 \pm 0.54^{\mathrm{d}}$ & $147.47 \pm 0.71^{\mathrm{b}}$ & $164.95 \pm 0.16^{\mathrm{c}}$ \\
LDH & $199.38 \pm 0.58^{\mathrm{a}}$ & $377.67 \pm 0.66^{\mathrm{c}}$ & $195.77 \pm 0.40^{\mathrm{a}}$ & $231.10 \pm 0.20^{\mathrm{b}}$ \\
ALP & $126.39 \pm 0.60^{\mathrm{b}}$ & $197.19 \pm 0.66^{\mathrm{d}}$ & $123.36 \pm 0.25^{\mathrm{a}}$ & $157.26 \pm 0.53^{\mathrm{c}}$ \\
\hline
\end{tabular}

Values that have a different superscript letter $(a, b, c, d)$ differ significantly $(p<0.05)$ among each other.

the observed reduction of antioxidant enzymatic level was restored in Group IV animals by squalene supplementation. Squalene possibly acts as a potent antioxidant as well as oxygen scavenging molecule and improves antioxidant defence status in liver tissue, which prevents MTX induced toxicity. It has been previously reported that squalene enhances antioxidant defence mechanism in hepatocytes of experimentally induced rats during drug toxicity by its antioxidant activity (Rajesh and Lakshmanan 2008).

Lipid peroxidation is an oxidative degradation process and is also responsible for nucleotide degradation. In the present study, the LPO level of MTX administrated group (Group II) was significantly higher than other groups. The LPO levels of squalene treated groups (Group I and IV) and Group I were in same range. Oxidative stress along with free radical generation and intense lipid peroxidation are major problems associated with MTX toxicity (Sener et al. 2006). MTX administration in experimental animals might initiate peroxidation of membrane lipids and production of free radicals which was reversed by dietary squalene supplementation. Squalene significantly counteracts the MTX induced lipid peroxidation and oxidative stress which is probably related to its free radical scavenging property. Senthilkumar et al. (2006b) stated that squalene is effective in attenuating lipid peroxidation reactions in the liver of experimental rats induced by anticancer drug and this observation is in line with the present study. Previously, it was reported that dietary squalene supplementation enhanced the antioxidant defense mechanism in experimental animals by reducing the elevated LPO level in cardiac tissue (Farvin et al. 2007). In addition, the protective effect of squalene against arsenic toxicity is mainly through the eradication of free radicals by means of its antioxidant and membrane stabilizing properties (Rajesh and Lakshmanan 2008).

\section{Effect of dietary squalene on AST, ALP, ALT and LDH levels of MTX administrated rats}

The levels of AST, ALP and ALT of MTX treated groups (Group II and IV) were increased in comparison with other groups, indicating impaired liver functions (Table 4). The lactate dehydrogenase (LDH) activity was also increased in MTX administrated groups (Group II and IV), whereas the prior squalene supplementation in Group IV animals showed significantly lower values than Group II animals (Table 4). Elevated levels of these marker enzymes in the liver tissue of experimental animals could be the indication of MTX related hepatotoxicity. MTX administration and its effect on liver marker enzymes were also reported by other investigators (Karthikeyan 2004; Ramadan et al. 2008). Moghadam et al. (2015) reported an increased serum ALT, AST and LDH activities in liver tissue homogenate due to hepatotoxicity induced by MTX. Methotrexate is metabolised in liver and such toxic metabolites produce oxidative stress subsequently initiating acute liver injury in experimental animals. In the present study, the treatment with squalene prior to the MTX injection resulted in the reduction of these parameters to control levels. Squalene by its free radical scavenging property possibly trapped the toxic metabolites produced in liver during the activation of this anticancer drug. Similarly, dietary squalene supplementation could be effective in preventing experimentally induced oxidative damage in hepatocytes and subsequent liver toxicity by its potential antioxidant and membrane stabilising activity. Earlier it was reported that dietary squalene supplementation effectively prevented the elevation of serum AST, ALT, ALP and LDH levels in kidney and liver tissue of experimental animals induced by cyclophosphamide (anticancer drug) by means of its antioxidant and free radical scavenging activity (Senthilkumar et al. 2006a). In addition, squalene supplementation decreased serum diagnostic marker enzymes' level and exerts protection on cardiac tissue of experimental animals by its membrane stabilising property (Farvin et al. 2004).

\section{Histopathological examination}

The examination of liver sections showed normal architecture of central vein, blood sinusoidal, portal triad and nucleus of hepatocytes in group I and III (Fig. 1 and 

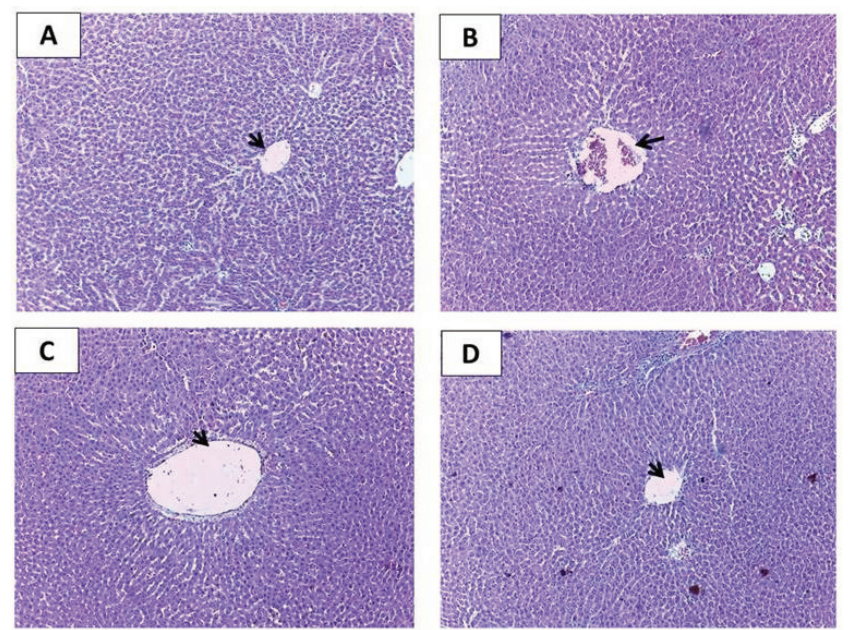

Figure 1. Histopathological analysis of liver sections of experimental animals. A; Microscopic view from the liver tissue of Group I. B; Microscopic view from the liver tissue of Group II. C; Microscopic view from the liver tissue of Group III. D; Microscopic view from the liver tissue Group IV. Arrow mark showing the central vein.

2). But MTX administrated groups (Group II and IV) displayed irregular central vein with massive inflammatory reactions, degenerative changes in portal triad, swelling of nucleus in hepatocytes and blood sinusoids were compressed. Dietary squalene supplementation to experimental animals considerably improved cell structure with regenerative changes in portal triad and cell sinusoidal with separated blood sinusoids. Histological studies also confirmed the hepatoprotective effect of squalene on MTX induced toxicity.

The histopathological observations in this study, confirmed that squalene inverted the increase of free radical generation. Thus, it is likely that the hepatoprotective mechanism of squalene could be due to its antioxidant activity and its ability to scavenge a wide range of free radicals. Earlier it was reported that squalene inhibit generation of free radicals and lipid hydroperoxides (Kabuto et al. 2013).

\section{Conclusion}

In conclusion, dietary supplementation of squalene can attenuate methotrexate-induced liver dysfunctions. Squalene could reduce the free radical formation during MTX induced toxicity. Therefore, squalene might serve as a potential as well as effective dietary supplement in reducing the complications of MTX induced liver injury and related hepatotoxicity during cancer treatment. Hence, the results of present study suggest that the oral in-take of squalene has prominent attenuating effect against
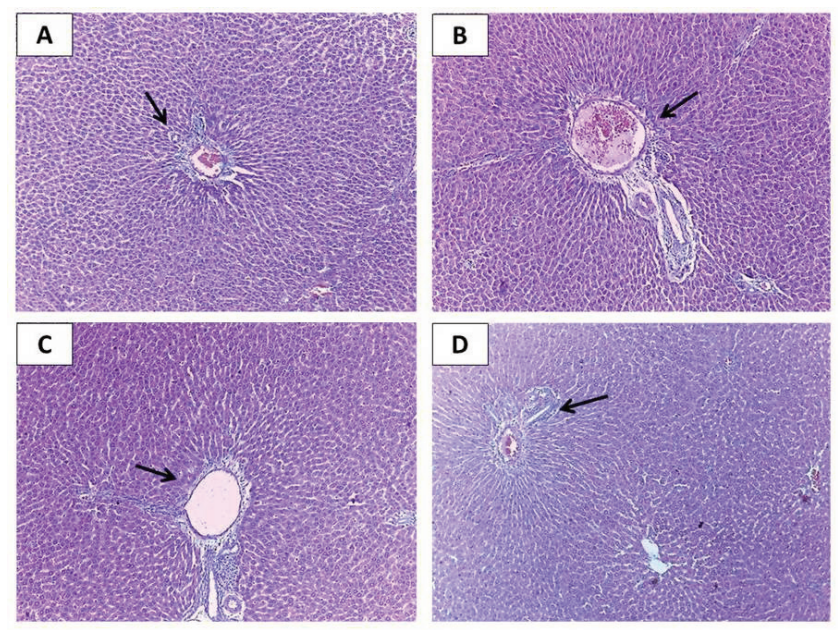

Figure 2. Histopathological analysis of liver sections of experimental animals. A; Microscopic view from the liver tissue Group I. B; Microscopic view from the liver tissue Group II. C; Microscopic view from the liver tissue Group III. D; Microscopic view from the liver tissue Group IV. Arrow mark showing portal triad structures (portal vein, hepatic artery, and bile duct).

oxidative stress and subsequent liver injury induced by MTX and can serve as therapeutic alternative.

\section{Acknowledgements}

The authors would like to express their sincere gratitude to ICAR for providing funds to carry out the research work under ICAR-National Fellow Scheme. The authors acknowledge the Director, ICAR-Central Institute of Fisheries Technology (ICAR-CIFT), Cochin, Kerala, India for providing the facilities to carry out this work and also for granting permission to publish the data acquired from the study. The authors are grateful to the Mrs. PA Jaya (Senior Technical Assistant) ICAR-Central Institute of Fisheries Technology (CIFT), Cochin, Kerala for providing technical support to carry out the analyses. Squalene used in the experiments was obtained as a gift from Mr. Sreedharan (Aasha Biochem, Kerala, India).

\section{References}

Abd El-Twab SM, Hoyden WG, Hussein OE, Mahmoud AM (2016) 18ß-Glycyrrhetinic acid protects against methotrexate-induced kidney injury by up-regulating the Nrf2/ARE/HO-1 pathway and endogenous antioxidants. Ren Fail 38(9):1516-1527.

Abdulzahra MD, Mohammed HF (2014) The possible protective effect of green tea extract against methotrexateinduced liver injury in male rats. Pharmanest 5(3):2034- 
2038.

Armagan A, Uzar E, Uz E, Yilmaz HR, Kutluhan S, Koyuncuoglu HR, Soyupek S, Cam H, Serel TA (2008) Caffeic acid phenethyl ester modulates methotrexate-induced oxidative stress in testes of rat. Hum Exp Toxicol 27:547552.

Atessahin A, Yilmaz S, Karahan I, Ceribasi AO, Karaoglu A (2005) Effects of lycopene against cisplatin-induced nephrotoxicity and oxidative stress in rats. Toxicology 212:116-123.

Block KI, Koch AC, Mead MN, Tothy PK, Newman RA, Gyllenhaal C (2008) Impact of antioxidant supplementation on chemotherapeutic toxicity: A systematic review of the evidence from randomized controlled trials. Int J Cancer 123:1227-1239.

Cetiner M, Sener G, Sehirli AO, Eksioglu-Demiralp E, Ercan F, Sirvanci S, Gedik N, Akpulat S, Tecimer T, Yegen BC (2005) Taurine protects against methotrexate-induced toxicity and inhibits leukocyte death. Toxicol Appl Pharmacol 209(1):39-50.

Cetinkaya A, Bulbuloglu E, Kurutas E and Kantarceken B (2006) N-acetylcysteine ameliorates methotrexateinduced oxidative liver damage in rats. Med Sci Monit 12(8):274-278.

Keshava C, Keshava N, Whong W-Z, Nath J, Ong T-m (1998) Inhibition of methotrexate-induced chromosomal damage by folinic acid in V79 cells. Mutat Res 397:221-228.

Ellman GL (1959) Tissue sulfhydryl groups. Arch Biochem Biophys 82:70-77.

Fadillioglu E, Yilmaz HR, Erdogan H, Sogut S (2003) The activities of tissue xanthine oxidase and adenosine deaminase and the levels of hydroxyproline and nitric oxide in rat hearts subjected to doxorubicin: protective effect of erdosteine. Toxicology 191:153-158.

Fan S, Ho I, Yeoh FL, Lin C, Lee T (1996) Squalene inhibits sodium arsenite-induced sister chromatid exchanges and micronuclei in Chinese hamster ovary-K cells. Mutat Res 368:165-169.

Farvin KHS, Anandan R, Kumar SHS, Shiny KS, Sankar TV, Thankappan TK (2004) Effect of squalene on tissue defence system in isoproterenol-induced myocardial infarction in rats. Pharmacol Res 50:231-236.

Farvin KHS, Anandan R, Sankar TV, Nair PGV, Thankappan TK (2005) Protective effect of squalene against isoproterenol induced myocardial infarction in rats. J Clin Biochem Nutr 37:55-60.

Farvin KHS, Kumar SHS, Anandan R, Mathew S, Sankar TV, Nair PGV (2007) Supplementation of squalene attenuates experimentally induced myocardial infarction in rats. Food Chem 105:1390-1395.

Frederick C Pearlman, Robert TY Lee (1974) Detection and measurement of total bilirubin in serum, with use of surfactants as solubilizing agents. Clin Chem 20(4):447-453.
Funk RS, Van HL, Becker ML, Leeder JS (2013) Low-dose methotrexate results in the selective accumulation of aminoimidazole carboxamide ribotide in an erythroblastoid cell line. J Pharmacol Exp Ther 347(1):154-63.

Goodsell DS (1999) The molecular perspective: methotrexate. Stem Cells 17:314-315.

Habig WH, Pabst MJ, Jakoby WB (1974) Glutathione-Stransferases: the first enzymatic step in mercapturic acid formation. J Biol Chem 249:7130-7139.

Hsu PC, Lan JL, Hsieh TY, Jan YJ, Huang WN (2003) Methotrexate pneumonitis in a patient with rheumatoid arthritis. J Microbiol Immunol Infect 36:137-140.

Imokawa S, Colby TV, Leslie KO, Helmers RA (2000) Methotrexate pneumonitis: review of the literature and histopathological findings in nine patients. Eur Respir J 15:373-81.

Jahovic N, Cevik H, Sehirli AO, Yegen BC, Sener G (2003) Melatonin prevents methotrexate-induced hepatorenal oxidative injury in rats. J Pineal Res 34:282-287.

Kabuto H, Yamanushi TT, Janjua N, Takayama F, Mankura M (2013) Effects of squalene/squalane on dopamine levels, antioxidant enzyme activity, and fatty acid composition in the striatum of Parkinson's disease mouse model. J Oleo Sci 62(1):21-28.

Kamimura H, Koga N, Ogari K, Yoshimura H (1992) Enhanced elimination of theophylline phenobarbital and strychnine from the bodies of rats and mice by squalene treatment. J Pharmacobiodyn 15:215-221.

Karthikeyan S (2004) Hepatotoxicity of isoniazid: A study on the activity of marker enzymes of liver toxicity in serum and liver tissue of rabbits. Indian J Pharmacol 36:247-249.

Khafaga AF, El-Sayed YS (2018) Spirulina ameliorates methotrexate hepatotoxicity via antioxidant, immune stimulation, and proinflammatory cytokines and apoptotic proteins modulation. Life Sci 196:9-17.

King J (1965a) The dehydrogenases or oxidoreductases lactate dehydrogenase. In Van D, Ed., Practical Clinical Enzymology. Van Nostrand, London. 83-93.

King J (1965b) The hydrolases- acid and alkaline phosphatases. In Van D, Ed., Practical Clinical Enzymology. Van Nostrand, London. 191-208

Kolli VK, Natarajan K, Isaac B, Selvakumar D, Abraham P (2014) Mitochondrial dysfunction and respiratory chain defects in a rodent model of methotrexate-induced enteritis. Hum Exp Toxicol 33(10):1051-1065.

Liang LS, Jackson J, Min W, Risovic V, Wasan KM, Burt HM (2004) Methotrexate loaded poly(L-lactic acid) microspheres for intra-articular delivery of methotrexate to the joint. J Pharm Sci 93:943-956.

Lowry OH, Rosebrough NJ, Farr AL, Randall RJ (1951) Protein measurement with Folin-phenol reagent.J Biol Chem 193:265-275. 
Miketova P, Kaemingk K, Hockenberry M, Pasvogel A, Hutter J, Krull K, Moore IM (2005) Oxidative changes in cerebral spinal fluid phosphatidylcholine during treatment for acute lymphoblastic leukemia. Biol Res Nurs 6:187-195.

Misra HP, Fridovich I (1972) The role of superoxide ion in the auto-oxidation of epinephrine and a simple assay for superoxide dismutase. J Biol Chem 247:3170-3175.

Miyazono Y, Gao F, Horie T (2004) Oxidative stress contributes to methotrexate induced small intestinal toxicity in rats. Scand J Gastroenterol 39:1119-1127.

Moghadam AR, Tutunchi S, Namvaran-Abbas-Abad A, Yazdi M, Bonyadi F, Mohajeri D, Mazani M, Marzban H, Łos MJ, Ghavami S (2015) Pre-administration of turmeric prevents methotrexate-induced liver toxicity and oxidative stress. BMC Complement Altern Med 15:246.

Mohur A, Cook IJY (1957) Simple methods for measuring serum levels of glutamic-oxalo acetic and glutamicpyruvic transaminase in routine laboratories. J Clin Pathol 10:394-399.

Mukherjee S, Ghosh S, Choudhury S, Adhikary A, Manna K, Dey S, Sa G, Das T, Chattopadhyay S (2013) Pomegranate reverses methotrexate-induced oxidative stress and apoptosis in hepatocytes by modulating Nrf2-NF- $x \mathrm{~B}$ pathways. J Nutr Biochem 24(12):2040-2050.

Neuman MG, Cameron RG, Haber JA, Katz GG, Malkiewicz IM, Shear NH (1999) Inducers of cytochrome P450 2E1 enhance methotrexate-induced hepatotoxicity. Clin Biochem 32:519-536.

Ohkawa H, Onishi N, Yagi K (1979) Assay for lipid peroxides in animal tissue by thiobarbituric acid reaction. Anal Biochem 95:351-358.

Paglia DE, Valentine WN (1967) Studies on the quantitative and qualitative characterization of erythrocyte glutathione peroxidise. J Lab Clin Med 70:158-169.

Quiles JL, Huertas JR, Battino M, Mataix J, Ramirez-Tortosa MC (2002) Antioxidant nutrients and adriamycin toxicity. Toxicology 180:79-95.

Ramadan AM. Hemeida, Omar M. Mohafez (2008) Curcumin attenuates methotraxate-induced hepatic oxidative damage in rats. J Egypt Nat Cancer Inst 20(2):141-148.

Rangasamy Rajesh, Pindath Thandayan Lakshmanan (2008) Antioxidant defense of dietary squalene supplementation on sodium arsenite-induced oxidative stress in rat myocardium. Int J Biomed Pharm Sci 2(2):98-102.
Richter E, Schafer SG (1982) Effect of squalene on hexachlorobenzene (HCB) concentrations in tissue of mice. J Environ Sci Health 17:195-203.

Mehrzadi S, Fatemi I, Esmaeilizadeh M, Ghaznavi H, Kalantar H, Goudarzi M (2018) Hepatoprotective effect of berberine against methotrexate induced liver toxicity in rats. Biomed Pharmacother 97(2):233-239.

Schwartzberg LS, Vogel WH, Campen CJ (2014) Methotrexate and fluorouracil toxicities: A collaborative practice approach to prevention and treatment. ASCO Post 5(7):234- 236.

Sener G, Eksioglu-Demiralp E, Cetiner M, Ercan F, Sirvanci S, Gedik N, Yegen BC (2006) L-Carnitine ameliorates methotrexateinduced oxidative organ injury and inhibits leukocyte death. Cell Biol Toxicol 22:47-60.

Senthilkumar S, Devaki T, Manohar BM, Babu MS (2006a) Effect of squalene on cyclophosphamide-induced toxicity. Clin Chim Acta 364(1-2):335-342.

Senthilkumar S, Yogeeta SK, Subashini R, Devaki T (2006b) Attenuation of cyclophosphamide induced toxicity by squalene in experimental rats. Chem Biol Interact 160(3):252-260.

Smith TJ (2000) Squalene: potential chemopreventive agent. Expert Opin Investig Drugs 9:1841-1848.

Sotiroudis SA, Kyrtopoulos (2008) Anticarcinogenic compounds of olive oil and related biomarkers. Eur J Nutr 47:69-72.

Takahara S, Hamilton BH, Nell JV, Kobra TY, Ogawa Y, Nishimura ET (1960) Hypocatalasemia: A new genetic carrier state. J Clin Invest 29:610-619.

Uz E, Oktem F, Yilmaz HR, Uzar E, Ozguner F (2005) The activities of purine-catabolizing enzymes and the level of nitric oxide in rat kidneys subjected to methotrexate: protective effect of caffeic acid phenethyl ester. Mol Cell Biochem 277:165-170.

Uzar E, Koyuncuoglu HR, Uz E, Yilmaz HR, Kutluhan S, Kilbas S, Gultekin F (2006a) The activities of antioxidant enzymes and the level malondialdehyde in cerebellum of rats subjected to methotrexate: protective effect of caffeic acid phenethyl ester. Mol Cell Biochem 291:63-68.

Uzar E, Sahin O, Koyuncuoglu HR, Uz E, Bas O, Kilbas S, Yilmaz HR, Yurekli VA, Kucuker H, Songur A (2006b) The activity of adenosine deaminase and the level of nitric oxide in spinal cord of methotrexate administered rats. Toxicol 218:125-133. 